\title{
Internasjonal legemotstand mot omskjæring av smågutter
}

\author{
Rådet for legeetikk, Norsk barnelegeforening, Legeforeningen og Barneombudet mener at omskjæring uten \\ medisinsk indikasjon hos et menneske uten samtykkekompetanse bryter med grunnleggende medisinsk- \\ etiske prinsipper. Aktuelle religiøse grupper bør utfordres til å finne alternative ritualer som kan ha generell \\ aksept i vår kulturkrets.
}

American Academy of Pediatrics (AAP) publiserte i 2012 et «policy statement» som konkluderer med at de medisinske fordelene ved omskjæring er større enn ulempene (1). Rapporten er brukt til å forsvare omskjæring av gutter, også i Norge (2). 38 leger fra 16 europeiske land og Canada, stort sett representanter for legeorganisasjoner, er i en artikkel i Pediatrics sterkt kritiske til denne rapporten og mener den bærer preg av at ikke-rituell omskjæring fortsatt er normen i USA (3). Legegruppen betviler fortolkningen og især vektleggingen av dataene det henvises til i rapporten. Tilstander som American Academy of Pediatrics mener taler for omskjæring, f.eks. redusert overføring av hivsmitte, er lite relevante $i$ land som vårt, og gutter kan selv ta stilling til saken når de blir samtykkekompetente. Ikke uventet har American Academy of Pediatrics svart på kritikken i samme nummer av Pediatrics (4).

To av de undertegnede (TM og SMN) er medforfattere av artikkelen i Pediatrics (3). Rådet for legeetikk (5), Norsk barnelegeforening (5), Legeforeningen (6) og Barneombudet (7) mener at omskjæring uten medisinsk indikasjon hos et menneske uten samtykkekompetanse bryter med grunnleggende medisinsk-etiske prinsipper, særlig siden det er irreversibelt, smertefullt og kan medføre alvorlige komplikasjoner. Diskusjonen må bli en avveining av denne medisinsk-etiske grunnregelen og foreldrenes rett til å følge sin religions pålegg. Dette er ikke enkelt.

Barneombudet har valgt å legge så stor vekt på barnets selvstendige rettigheter at man mener rituell omskjæring bør forbys inntil gutten selv kan bestemme, det vil si fra 16 års alder. Rådet for legeetikk og Barnelegeforeningen har det samme prinsipielle synet, men ser det sterke religiøse påbudet $\mathrm{og}$ mener at et forbud mot tidlig omskjæring vil kunne føre til at praksisen fortsetter i det skjulte og blir utført medisinsk uforsvarlig. Rådet og Barnelegeforeningen vil derfor ikke forby omskjæring, men har påpekt at inngrepet må utføres medisinsk forsvarlig og at kostnaden ikke bør dekkes av det offentlige.

Vår utfordring til de aktuelle religiøse gruppene er at de finner frem til alternative ritualer som kan ha generell aksept i vår kulturkrets i dag. Synet på menneskerettigheter og barns rettigheter sett i forhold til

\section{«Omskjæring uten medisinsk indikasjon hos et menneske uten samtykkekompetanse bryter med grunn- leggende medisinsk- etiske prinsipper»}

religiøse krav og tradisjoner har endret seg mye opp gjennom tidene, og det er rimelig at det fortsatt skjer endringer i takt med ny kunnskap og endringer i etiske og juridiske normer.

\section{Trond J. Markestad}

trond.markestad@helse-bergen.no

Rådet for legeetikk

\section{Anne Lindboe}

Barneombudet

\section{Solveig Marianne Nordhov}

Norsk barnelegeforening

Trond Markestad (f. 1945) er professor i pediatri ved Universitetet i Bergen, forskningskoordinator ved Barneklinikken, Haukeland universitetssykehus og leder i Rådet for legeetikk i Den norske legeforening. Forfatter har fylt ut ICMJE-skjemaet og oppgir ingen interessekonflikter.
Anne Lindboe (f. 1971) er spesialist i barnesykdommer. Hun er barneombud.

Forfatter har fylt ut ICMJE-skjemaet og oppgir ingen interessekonflikter.

Solveig Marianne Nordhov (f. 1967) er spesialist i barnesykdommer, med spesialkompetanse i neonatalogi og sosialpediatri. Hun er overlege ved Barneavdelingen ved Universitetssykehuset Nord-Norge og leder for Norsk barnelegeforening.

Forfatter har fylt ut ICMJE-skjemaet og oppgir ingen interessekonflikter.

\section{Litteratur}

1. American Academy of Pediatrics Task Force on Circumcision. Circumcision policy statement. Pediatrics 2012; 130: 585-6.

2. Chaudhry FA, Knutsen L, Kirschner R. Barneleger, gynekologer og fødselsleger er positive til gutteomskjæring. Tidsskr Nor Legeforen 2013; 133: 264-5.

3. Frisch M, Aigrain Y, Barauskas V et al. Cultural Bias in the AAP's 2012 technical report and policy statement on male circumcision. Pediatrics 2013. 131: $796-800$.

4. American Academy of Pediatrics Task Force on Circumcision. Cultural bias and circumcision: the AAP task force on circumcision responds. Pediatrics 2013; 131: $801-4$.

5. Høringsuttalelse fra Den norske legeforening. www.regjeringen.no/pages/16338045/ DenNorskeLegeforening.pdf (9.4.2013).

6. Høringsuttalelser fra Rådet for legeetikk og Norsk barnelegeforening. https://legeforeningen.no/ Legeforeningen-mener/Horinger/Horing--forslag-om-lovregulering-av-rituell-omskjaring/ (9.4.2013).

7. Høringsuttalelse fra Barneombudet. www.barneombudet.no/sfiles/82/28/2/file/ barneombudet-horingssvar-om-rituellomskjaring-av-gutter.pdf (9.4.2013).

Mottatt 3.4. 2013 og godkjent 16.4. 2013. Medisinsk redaktør Are Brean

Publisert først på nett 